\title{
Innovation of Ideological and Political Education for College Students in the Micro Age
}

\section{Men Chuankai}

\author{
ChangJiang Institute of Technology, Wuhan, 430212, China
}

Keywords: micro age; college students' ideological and political education; innovation

\begin{abstract}
With the rapid development of science and technology, and the "micro era", which takes micro-blog and WeChat as reprentatives, has come all round. The advent of "micro era" has brought new opportunities and challenges to the ideological and political education in colleges and universities. Therefore, the study of the ideological and political education of college students under the background of "micro era" is the way to create a new way of ideological and political education in colleges and universities. The path has become a difficult problem for the ideological and political education in colleges and universities. This paper aims to study the innovation of the path of ideological and political education of college students.
\end{abstract}

\section{Introduction}

With the continuous development of information technology, the "micro era" has come all round. Under the background of "micro age", the study of the creative work of Ideological and political education of college students can promote the formation of the world outlook and values of contemporary college students, and help the students to purify the network environment and build science. The ideological and political education system enables college students to better realize their own development, use the network to carry out ideological and political learning, and then improve the comprehensive quality of college students, and train them into a high quality compound talents needed in the new era. Next, the author will discuss how to innovate the path of College Students' Ideological and Political Education under the background of "micro age", and hopes to provide some suggestions for the development of Ideological and political education in Colleges and universities.

The concept of "micro age" and the characteristics of its communication. As far as the present stage is concerned, there is no clear definition for the "micro era" in our academic circles. But from the point of view, the author thinks that the "micro era" is a relative concept, the product of the development of science and technology, the full arrival of the information age, and its essence is that people use the Internet technology and the mobile information technology. The processing and communication of information formed by words, pictures or videos, and full timeliness, efficiency and interaction. As the "micro era" is a new way of communication derived from the information society, the transmission characteristic of the "micro era" is first of all the media main body. This is because under the "micro era" background, micro-blog, WeChat and other communication tools are widely used. and as new media tool, their registration and use are very popular in daily life, regardless of your education, origin or property situation, we can carry on the registration of WeChat, micro-blog, and then publish views, the dissemination of information. Second, the characteristic of the "micro era" is the fragmentation of information. In today's mobile communication technology, people can use the mobile phone to communicate quickly, to participate in comments, to send and receive messages more quickly, which are limited by time and region. However, although these short and excellent information is more popular with people, the information is fragmented, which makes the source of information more rampant. In addition, the characteristics of information dissemination in the "micro era" also include the centralization of information exchange and the viral transmission, which is very easy to have a negative impact on the guidance of public opinion. Therefore, the "micro era" has brought many challenges to the ideological and political work of college students. 


\section{The Problems Faced by College Students' Ideological and Political Education under the Background of "Micro Era"}

Under the background of "micro era", the problems faced by the ideological and political education of college students are first reflected in the micro era information environment which seriously affects the value orientation of contemporary college students. Under the "micro era" background, information can be delivered quickly, and the number of people will be flooded into the information ocean, and influence their own value orientation. This problem is particularly obvious in the ideological and political work in Colleges and universities. The contemporary college students can read all kinds of information on the network, and accept the influence from all aspects. However, we should pay attention to the fact that the network information is a double-edged sword. It brings convenience to us and presents some bad information in front of contemporary college students. If the university students can not resist themselves, they will be affected by these unhealthy information, resulting in the wrong value orientation. In addition, there are many network games in the "micro era" information platform. Because of their poor self-control ability, once they are addicted to the game world, they will spend a lot of time and energy on the game, which will seriously affect the ideological and political work of college.

Under the background of "micro era", the problems faced by college students' Ideological and political education are that the old teaching mode is impacted by information environment. Under the background of the "micro era", many new medias are spread out in an endless stream. These new medias are changing the way of life and the way of thinking. However, in the traditional ideological and political teaching, the teaching mode is always based on Teachers' teaching, while assisting lectures and social reality. Therefore, the teaching mode of Ideological and political education in Colleges and universities has been seriously impacted.

Under the background of "micro era", the problems faced by college students' Ideological and political education are also reflected in the information environment of the micro era, which weakens the teaching and guiding function of teachers. Under the background of "micro era", the flexible and changeable network learning environment enables students to accept and learn from network knowledge anytime and anywhere. Therefore, the guiding function of teachers is gradually weakening. However, ideological and political education in Colleges and universities is a subject which requires teachers to give full play to their own guiding functions. If teachers are not able to carry out effective guidance in the process of education, the construction of Ideological and political work in Colleges and universities will be less than satisfactory and can not achieve the purpose of improving the ideological and theoretical level of college students. In addition, because of the weakening of the new media in the background of "micro era", the students will become scattered in the process of accepting the ideological and political education, and the undisciplined ideological and political education mentality is very bad for the ideological and political education in Colleges and universities.

\section{The Innovation Path of Ideological and Political Education for College Students under the Background of "Micro Era"}

To innovate the ideological and political education of College Students under the background of "micro era", we must first strengthen the construction of Ideological and political teachers in Colleges and universities. The full arrival of the "micro era" and the rapid development of the new media have put forward new requirements for the ideological and political education in Contemporary Colleges and universities. At the same time, the ideological and political education in Colleges and universities is facing new opportunities and challenges. Therefore, the contemporary colleges and universities should adhere to the reality and promote the comprehensive improvement of Ideological and political education workers. In order to improve the comprehensive quality of Ideological and political education workers in Colleges and universities, we should strengthen the construction of teachers' strength in Colleges and universities and improve the ideological and political theory of teachers. At the same time, teachers should be able to use the new media in their 
background of "micro era" in the work to make full use of the education funds in micro-blog and WeChat. So that we can build a better system of Ideological and political education in Colleges and Universities under the background of "micro era" and keep pace with the times. At the same time, in order to better cope with the uncontrollability of information education resources under the background of "micro era", we should also better cope with problems in the ideological and political education work, and better carry out ideological and political education in Colleges and universities. In addition, in the process of strengthening the construction of teachers, we should pay more attention to cultivating the ability of Ideological and political educators to identify the network information, to strengthen the ability of teachers to screen and integrate information, and then we can establish a better network learning system for students which can reduce the chance of students contacting malicious information maximally ,stop the spread of unhealthy atmosphere and further carry out ideological and political work in Colleges and universities.

To innovate the ideological and political education of College Students under the background of "micro era", we should increase effective communication between teachers and students, and pay attention to the guidance of students. With the advent of the "micro era", the teaching and guiding function of teachers is gradually weakening. This is because in the new media era, students can learn more through the network resources, which makes the teachers and students lack effective communication, and there is a huge thinking barrier between teachers and students. So we must strengthen the effective communication between teachers and students in the process of Creative College Students' Ideological and political work, and then rewin the trust of the students and better guide the ideological and political education. The author suggests that our schools should establish the official WeChat, micro-blog, the information update platform and fully respect for the development of students' personality, know the state of students' psychological development, and establish a more harmonious relationship with the students, form more effective interaction between teachers and students, let teachers play their own guiding functions of Ideological and political education fully, and realize the innovation of Ideological and political work in the background of "micro era".

To innovate the ideological and political education of College Students under the background of "micro era", we should also make use of new media to reform educational methods in specific teaching work. The new media is the core of the "micro era" thought, using the new media to reform the ideological and political education in Colleges and universities, which is not only the specific requirement of the "micro era", but also in line with the characteristics of the development of college students. For example, WeChat and micro-blog are the new media accepted by the majority of students in the background of "micro era". Therefore, our ideological and political educators in Colleges and universities should strive for WeChat and micro-blog as the main positions for ideological and political work, and use micro platforms to better carry out ideological and Political Education, and guide the ideological concept of college students through the publication of information, instill the new era of socialist core value system, the introduce social hot issues into the classroom to stimulate students' discussion, and enable students to better express their own views and form ideological and political thinking, and then improve the efficiency of Ideological and political work in Colleges and universities, and better cultivate our students. The new age needs new young people with ability and quality.

To innovate the ideological and political education of College Students under the background of "micro era" should also improve the "micro literacy" of the students in the ideological and political education. Improving the micro literacy of college students can better enable students to use the new media derived from the "micro era" background to study and strengthen the construction of Ideological and political work in Colleges and universities. On the one hand, we should use the combination of theory and practice in teaching to interpret the contemporary ideological and political culture for students. At the same time, we should connect the reality of life, students find cases from life, and then promote the formation of correct values and world outlook, promote the development of the political theory of contemporary college students, and improve college students' ability to solve problems and analyze problems by using ideological and political theory. On the 
other hand, our professors should also teach students how to use new media to study in specific teaching work, and then improve their "micro literacy" so that students can better improve their thinking judgment under the background of "micro age", improve personal network moral cultivation, and develop good network learning habits. It will further promote the effective development of Ideological and political education in Colleges and universities, and innovate the ideological and political education in Colleges and universities in a real sense.

To innovate the ideological and political education of College Students under the background of innovation "micro era", we must establish a scientific evaluation system in Ideological and political education, and better serve the construction of Ideological and political work in Colleges and universities. In the past, the direct way to assess the level of Ideological and political education for college students is to do the exam. This backward evaluation method is out of date. If a new and scientific evaluation system can not be set up in the ideological and political education for college students, any reform and innovation will be in the form without any effect. . Based on this, the author suggests that we should establish a scientific evaluation system in the ideological and political education of innovative colleges and universities, and evaluate students in multiangle and multi-level, so as to better test the teachers' teaching effect, avoid ideological and political education becoming formalistic, and emerge unfavorable teaching or the neglect of teaching. And then we can comprehensively strengthen the ideological and political education work of college students.

To innovate the ideological and political education of College Students under the background of the innovation of "micro era", we should also build the ideological exchange platform for the students in the specific work, and then grasp the students' ideas, aim at the creative work of Ideological and political education in Colleges and universities. Under the background of "micro age", the students' divergent thinking is stronger and their horizons are more open. If the ideological and political education is just carried out in education work, but ignore the development of the students' individuality, the innovation of any education will be futile. Therefore, the teachers must think of the innovation in colleges and universities. In the political education work, we should rely on the new media to build the ideological exchange platform for students, and then let the students better communicate through the exchange platform. At the same time, the teachers can use the exchange platform to pay attention to the students' ideological development, and then better use the communication platform sound to know the students' thought and do a good job of College Students' thinking. We want to improve our ideological and political education through political innovation.

\section{Conclusion}

In summary, under the background of "micro era", studying the new path to study the ideological and political education of college students can better complete the ideological and political education work for students, and let the students cultivate the correct outlook on life and values. As the ideological and political education workers in Colleges and universities, we must face the opportunities and challenges brought from "micro era" for ideological and political education, and then constantly forge ahead, strengthen the communication between teachers and students, and innovate the mode of education, so as to realize the innovation of Ideological and political work of college students, and complete the life endowed by the state.

\section{References}

[1] Li Y. Research on the Innovation of "Post-90s" College Students' Ideological and Political Education in the "Micro-age"[J]. Science Education Article Collects, 2016.

[2] Li Y. Research on the Innovation of "Post-90s" College Students' Ideological and Political Education in the "Micro-age"[J]. Science Education Article Collects, 2016.

[3] Gong-Xian X U, Yang H W, Marxism S O, et al. The Innovation of Ideological and Political 
Education for Postgraduates in the View of Micro Age [J]. Journal of Nanchang Normal University, 2016.

[4] Liu Y. On the Innovation and Development of Ideological and Political Education for College Students in the New Period [J]. Science Education Article Collects, 2018.

[5] Fu X, University H. Research on the innovation of ideological and political education method for college students [J]. Journal of Jiamusi Vocational Institute, 2016.

[6] Zhang W B, University S. Research on the innovation of college students' ideological and political education in the new era [J]. Journal of Jiamusi Vocational Institute, 2017(icicee). 